\title{
Ultrastructural analyses in the hippocampus CA1 field in Shank3-deficient mice
}

\author{
Neha Uppal ${ }^{1,2,3,4,6}$, Rishi Puri ${ }^{1,2}$, Frank Yuk ${ }^{1,2}$, William G M Janssen ${ }^{1,2}$, Ozlem Bozdagi-Gunal ${ }^{2,3,5}$, \\ Hala Harony-Nicolas ${ }^{2,3,5}$, Dara L Dickstein ${ }^{1,2,4}$, Joseph D Buxbaum ${ }^{2,3,4,5}$ and Patrick R Hof f $^{1,2,3,4^{*}}$
}

\begin{abstract}
Background: The genetics of autism spectrum disorder (hereafter referred to as "autism") are rapidly unfolding, with a significant increase in the identification of genes implicated in the disorder. Many of these genes are part of a complex landscape of genetic variants that are thought to act together to cause the behavioral phenotype associated with autism. One of the few single-locus causes of autism involves a mutation in the $\mathrm{SH} 3$ and multiple ankyrin repeat domains 3 (SHANK3) gene. Previous electrophysiological studies in mice with Shank3 mutations demonstrated impairment in synaptic long-term potentiation, suggesting a potential disruption at the synapse.

Methods: To understand how variants in SHANK3 would lead to such impairments and manifest in the brain of patients with autism, we assessed the presence of synaptic pathology in Shank3-deficient mice at 5 weeks and 3 months of age, focusing on the stratum radiatum of the CA1 field. This study analyzed both Shank3 heterozygous and homozygous mice using an electron microscopy approach to determine whether there is a morphological correlate to the synaptic functional impairment.
\end{abstract}

Results: As both synaptic strength and plasticity are affected in Shank3-deficient mice, we hypothesized that there would be a reduction in synapse density, postsynaptic density length, and perforated synapse density. No differences were found in most parameters assessed. However, Shank3 heterozygotes had significantly higher numbers of perforated synapses at 5 weeks compared to 3 months of age and significantly higher numbers of perforated synapses compared to 5-week-old wildtype and Shank3 homozygous mice.

Conclusions: Although this finding represents preliminary evidence for ultrastructural alterations, it suggests that while major structural changes seem to be compensated for in Shank3-deficient mice, more subtle morphological alterations, affecting synaptic structure, may take place in an age-dependent manner.

Keywords: Autism, Shank3, Electron microscopy, CA1, Hippocampus, Stratum radiatum, Synapse

\section{Background}

The behavioral symptoms that currently define autism have yet to be rooted in a cause, though it is generally understood that these symptoms originate from alterations in the brain. Many studies have validated this hypothesis, as regionally specific abnormalities including reduced neuronal size, decreased neuronal number, and cortical disorganization are present in individuals with autism (e.g., [1-6]). The abnormalities in neuronal

\footnotetext{
* Correspondence: patrick.hof@mssm.edu

${ }^{1}$ Fishberg Department of Neuroscience, Icahn School of Medicine at Mount

Sinai, One Gustave L Levy Place, Box 1639, New York, NY 10029, USA

${ }^{2}$ Friedman Brain Institute, Icahn School of Medicine at Mount Sinai, New

York, NY, USA

Full list of author information is available at the end of the article
}

architecture imply corresponding disruptions in communication among neurons, which likely manifest at the synapse. Of particular relevance is the growing number of synaptic function-related genes implicated in autism. The Src homology 3 and multiple ankyrin repeat domains 3 (SHANK3) gene, which encodes for the postsynaptic scaffolding protein SHANK3/ProSAP2, has been identified as one of the few genes which can by itself lead to autism when mutated. SHANK3 was identified as the cause of the neurobehavioral manifestations of the 22q13 deletion syndrome, or the Phelan-McDermid syndrome (PMS; [7]). Patients with PMS not only exhibit developmental, intellectual, and language delays as well as motor deficits but also frequently demonstrate autistic 
behaviors [8-11]. Although patients with $22 \mathrm{q} 13$ deletions have varying deletion sizes, SHANK3 is a gene that has been consistently implicated [12] and was later found to be exclusively affected through point mutations in some individuals with PMS [10,13-15], leading to the conclusion that this gene is likely a strong candidate gene for autism as well. Upon further analysis, SHANK3 variants were identified in patients ascertained with autism $[9,11$, 13, 16-18]. Given its crucial role in the etiology of PMS and autism, studying the impact of a loss of SHANK3 will allow for a detailed assessment of cellular and molecular mechanisms that underlie pathology.

SHANK3 belongs to a family of SHANK proteins, all of which have multiple domains for protein-protein interaction $[19,20]$. Each of these domains interacts with specific proteins, in particular with cytoskeletal proteins, cell adhesion proteins, and ionotropic and metabotropic glutamate receptors [21-25], some of which are also implicated in autism (e.g., NLGN3, NLGN4, SHANK1, SHANK2). SHANK3 is strongly expressed at the postsynaptic density (PSD), as it is part of a molecular assembly (which includes PSD-95/GKAP/Shank/Homer) which comprises approximately $27 \%$ of the total protein molecules in the PSD; Shank3 is estimated to comprise $\sim 5 \%$ of the total protein molecules in the PSD [26]. To determine the effect of a loss of one copy of SHANK3, as observed in patients with PMS [11], Bozdagi and colleagues [27] created a mouse with a disruption in full-length Shank3, which is a form known to be specifically disrupted in patients with autism (e.g., [18]). Functionally, the authors demonstrated that Shank3 heterozygotes display significant impairments in long-term potentiation (LTP) maintenance when recording from the stratum radiatum in the CA1. Furthermore, they reported a significant decrease in $\alpha$-amino-3-hydroxy-5-methyl-4-isoxazole propionic acid (AMPA) receptor-mediated field potentials in the Shank3 heterozygotes as well as a reduction in the amount of glutamate receptor subunit 1 (GluA1), an AMPA receptor subunit. Subsequently, Yang and colleagues [28] corroborated the electrophysiologic impairments in Shank3 heterozygous mice and found impairments in both LTP induction and maintenance in Shank3 homozygous mice. While Shank3 protein is widely expressed throughout the brain, it is concentrated in the thalamus, cerebellum, and hippocampus [29]. Because of the impairment in LTP seen in Shank3 heterozygous and homozygous mice, Shank3 expression in the hippocampus was particularly interesting to assess.

Given these findings and the crucial role of SHANK3 in the etiology of PMS and autism, this study examined ultrastructural alterations in the above Shank3 mouse model of autism. The primary morphological parameters assessed in the current study were synapse density, perforated synapse density, and PSD length in the Shank3- deficient mice, due to the likelihood these parameters would be affected by a loss of Shank3, given its role in the PSD and LTP (e.g., [27, 30]). Differences in PSD length would indicate a change in the ratio of plastic and stable spines, as PSD length is correlated with spine head size and type. We also assessed perforated synapses, which are distinguished by a discontinuous PSD despite being part of a single synapse. Perforated synapses have been implicated in many functions in the context of learning and memory, including maintenance of spatial learning ability, activity-dependent synaptic plasticity, and LTP induction [31-35]. The formation of a perforation in the synapse, which transiently occurs during LTP induction, is thought to enhance the efficacy of synaptic transmission due to the increase in PSD area and therefore increase in AMPA- and N-methyl-Daspartic acid (NMDA)-receptor content [33, 34, 36]. Their formation, however, remains a subject of debate, with some postulating that non-perforated synapses become perforated, as a transient intermediary structure, to then form two separate synapses (for example, [37]), others postulating that perforated and non-perforated synapses are completely separate populations of synapses that develop in unique ways (for example, [38]), and others suggesting that perforations transiently develop in non-perforated synapses to briefly increase the efficacy of the synapse, which will later form back into its original non-perforated structure (for example, [39]). Despite the debate on perforated synapse origin and development, their role in increasing the efficacy of a synapse is generally agreed upon and is the reason we are assessing their presence in our mouse model. Changes in synapse functioning, as measured through morphological changes, would likely lead to alterations in normal neuronal functioning. Alterations in neuronal functioning, in turn, might be reflected in the behavioral changes that currently characterize individuals with disorders such as PMS and autism. There are very few studies that have assessed hippocampal differences in postmortem brains from this patient population and that have identified neuronal abnormalities that may affect synaptic functioning. Neuronal abnormalities in the hippocampus in patients with autism include reduction in neuron volume, dendritic branching, and nucleus volume [3, 6], although to our knowledge there are no studies that have quantified changes at the synaptic level in patients with autism. Unfortunately, as of yet, there have been no postmortem studies in individuals with PMS nor specifically on individuals with autism that have a disruption in SHANK3; however, we can presume that this region is likely also affected in these individuals, as they present with similar behavioral symptoms.

In the current study, synaptic measures were assessed at two time points: 5 weeks, corresponding to an early 
adolescence stage near sexual maturity when the relevant brain region is undergoing constant synaptic pruning, and 3 months, corresponding to a young adult that is socially mature and has a reduced rate of synaptic turnover. These ages were consistent with previous studies conducted on this mouse model [27, 28], which allowed for direct comparison of the synaptic measures in this study with electrophysiological and behavioral measures from earlier studies. Overall, this study aimed to clarify the effect of Shank3 deficiency on synapse morphology.

\section{Methods}

\section{Animals}

All procedures were compliant with the National Institute of Health Guidelines for the Care and Use of Experimental Animals and were approved by the Institutional Animal Care and Use Committee at the
Icahn School of Medicine at Mount Sinai. Shank3 heterozygous and homozygous mice were generated using homologous recombination to delete the ankyrin repeat domain of Shank3. This constitutive knockout mouse model of Shank3 disruption has been previously characterized in detail $[27,28]$. The study included 15 C57BL/ 6 male mice (5 weeks old: 5 Shank3 homozygous mice, 5 Shank3 heterozygous mice, and 5 wildtype mice) and 15 C57BL/6 male mice (3 months old: 5 Shank3 homozygous mice, 5 Shank 3 heterozygous mice, and 5 wildtype mice). Mice were group-housed and were given standard mouse chow and water ad libitum.

\section{Perfusion and tissue processing}

Prior to perfusion, mice were anesthetized with $15 \%$ chloral hydrate. The mice were perfused with $1 \%$ cold paraformaldehyde ( $\mathrm{pH}$ 7.2-7.4) in phosphate buffer saline (PBS) for $1.5 \mathrm{~min}$. This was followed by a solution
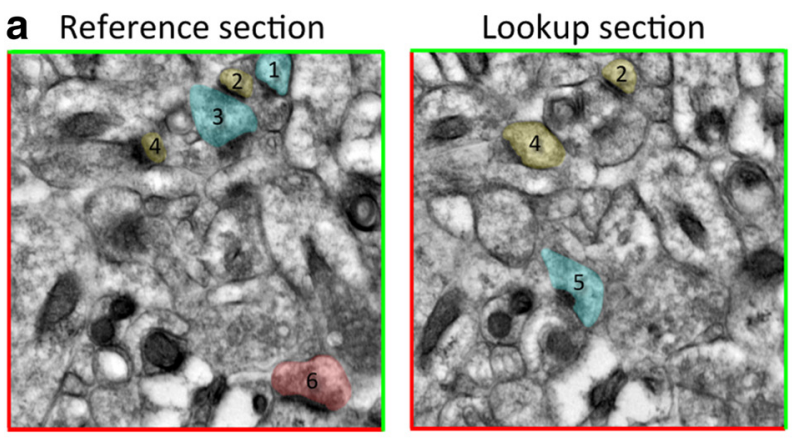

b Perforated synapse density

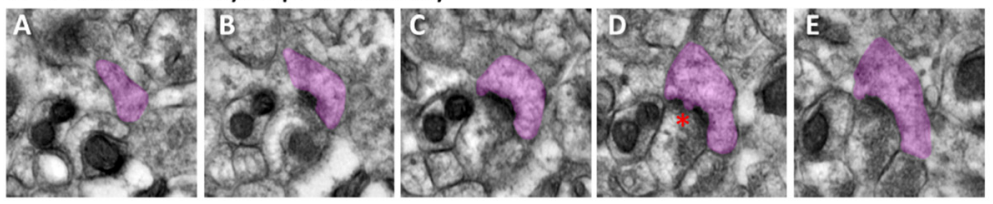

C Postsynaptic density length

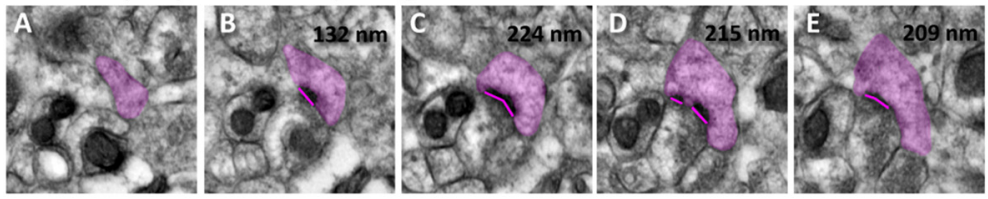

d Spine head size

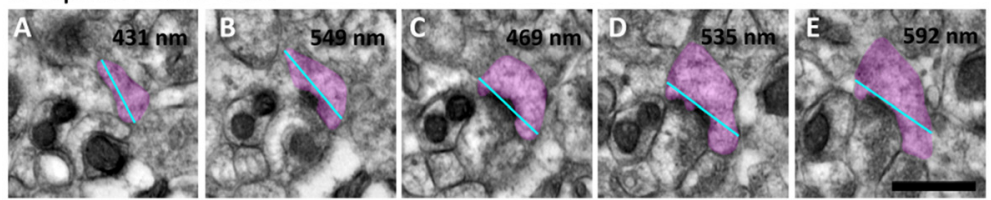

Fig. 1 The disector method. a Representative picture of a reference and lookup section in a set of serial images labeled $A-E$, with $A$ as reference and $B$ as lookup; note the inclusion (green) and exclusion (red) lines bordering the boundaries of images. Synapses that are present in both the reference and lookup sections are not counted towards synapse density (synapses 2 and 4; yellow) nor are synapses in which the pre- or postsynapse touch the exclusion lines (synapse 6; red). Each unique synapse in the lookup section (synapse 5; blue) is followed through the rest of the series to identify perforated synapses (red asterisk; $\mathbf{b}$ ) and measure postsynaptic density length, indicated with pink lines (c), and spine head size, indicated by blue lines (d). Scale bar $=500 \mathrm{~nm}$ 
of $4 \%$ paraformaldehyde in $0.1 \mathrm{M}$ PBS and $0.125 \%$ glutaraldehyde for $10.5 \mathrm{~min}$ at $5 \mathrm{ml} / \mathrm{min}$. The brain was then removed from the skull and postfixed in a $4 \%$ paraformaldehyde/0.125\% glutaraldehyde solution overnight at $4{ }^{\circ} \mathrm{C}$. The brain was washed in phosphate buffer $(\mathrm{PB})$, cut into $250-\mu \mathrm{m}$-thick sections using a vibratome, and stored in PB overnight. The sections were cryoprotected the next day in a graded glycerol/PB solution. After remaining in a $30 \%$ glycerol solution overnight, the CA1 was manually microdissected into blocks (four per animal) that underwent cryosubstitution and low-temperature embedding as described in [40].

Once the polymerization was complete, the hardened capsules were removed from the cryosubstitution system and stored at room temperature. Block faces were trimmed to include the stratum pyramidale, stratum radiatum, stratum lacunosum-moleculare, and white matter. At least eight consecutive ultrathin sections were cut at $90 \mathrm{~nm}$ with a diamond knife (Diatome, Bienne, Switzerland) on an ultramicrotome (Reichert-Jung) and mounted onto a Formvar-supported slot grid (Electron Microscopy Sciences).

\section{Morphological analysis}

Serial section imaging was carried out at $75 \mathrm{kV}$ on a Hitachi H-7000 transmission electron microscope (Hitachi High Technologies America) with an AMT Advantage CCD camera (Advanced Microscopy Techniques). Eight sets of five serial sections of distinct regions in the stratum radiatum of the CA1 were imaged at $\times 15,000$. Electron micrographs were adjusted for brightness, contrast, and sharpness using Adobe Photoshop (Photoshop CS4, version 11.0.2) prior to being analyzed. All morphological analysis was carried out in Adobe Photoshop.

Synapse density and perforated synapse density were analyzed using the disector method (Fig. 1; [41]). Asymmetric axospinous synapses were defined as having an asymmetric PSD, presynaptic vesicles, a clear synaptic cleft, and an evident spine head. All synapses present in the first ("reference") section, but not the second ("lookup"), were used for calculations of synapse density, along with each synapse that was present in the second section, but not the first. To calculate perforated synapse density, all unique synapses from the second section were followed through the remaining three sections to determine whether the synapses were perforated (defined as a clear break in the PSD). PSD length was measured in each section with a resolution of $0.5 \mu \mathrm{m} /$ 113 pixels. The longest measured PSD length was used as the representative measure for that synapse. This process was also completed for spine head size, measuring the widest point of the spine head parallel to the PSD. The longest length of spine head was used as the representative measure of that synapse. This entire

\section{a}

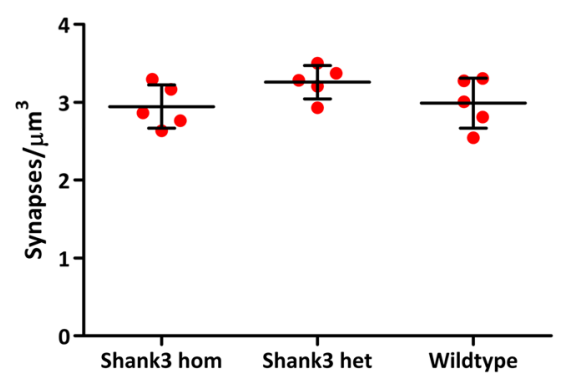

b Mean perforated synapse density (5 weeks

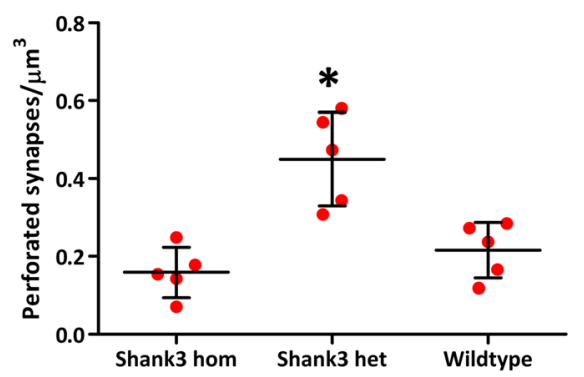

Mean synaptic density (3 months)

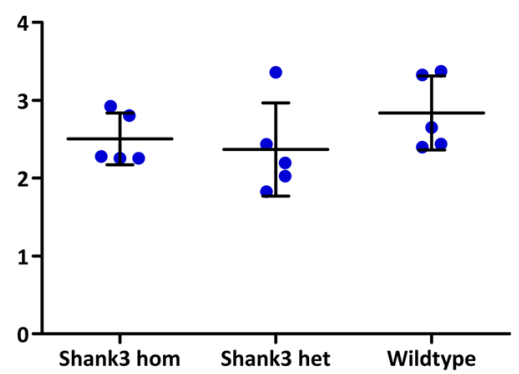

Mean perforated synapse density (3 months)

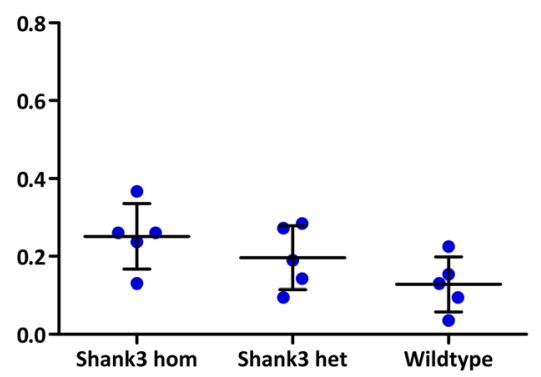

Fig. 2 Synapse density and perforated synapse density across ages and genotypes. No change in density of synapses (a) was found in 5-weekold mice (left) and 3-month-old mice (right). A significant increase in perforated synapses (b) is shown in 5-week-old Shank3 heterozygous mice (left), but no difference was seen at 3 months (right). Standard deviation indicated with vertical black lines, mean indicated by horizontal black line; *denotes significance 
process was then repeated for each set but using the last two sections as the reference and lookup sections; this allowed for approximately 400-600 synapses recorded per animal. The disector area was $58.65 \mu^{2}$, and disector height was $180 \mathrm{~nm}$; therefore, the synapse density was calculated as the total number of counted synapses from both the first and second sections divided by the total volume of the disector $\left(10.56 \mu \mathrm{m}^{3}\right)$.

\section{Statistical analysis}

We compared two ages and three genotypes of mice. Both the 5-week and 3-month group had an $n=5$ per genotype, with a total of 15 mice each. Comparisons of potential genotypic variations within one age group were determined using one-way analysis of variance (ANOVA). To reduce type I error while comparing several means, a Tukey post hoc test was used to calculate whether there were significant differences between pairs of genotypes. Calculations were performed with GraphPad Prism (version 5). To determine whether there was an interaction between age and genotype on the parameters assessed, we used two-way ANOVA to assess for significant differences and corrected for multiple comparisons using the Tukey post hoc test. Calculations were performed with SPSS (version 20). A $p$ value of 0.05 was used as the criterion for statistical significance.

\section{Results}

The first measure of synaptic pathology we assessed in these mice was overall synaptic density and perforated synapse density. No difference was found in synapse density between Shank3 heterozygous, Shank3 homozygous, and wildtype 5 -week-old mice $\left(F_{(2,12)}=1.915, p=0.19\right.$; Fig. 2a). This result remained consistent into adulthood, with 3-month-old mice also showing no difference in synapse density across the three genotypes $\left(F_{(2,12)}=1.256\right.$, $p=0.32$; Fig. 2a), though 5-week-old mice had significantly greater synapse density than 3 -month-old mice $(p=0.002)$. There was no significant interaction between genotype and age for synapse density $\left(F_{(2,24)}=2.254, p=0.127\right)$. However, perforated synapse density was significantly different in 5week-old mice across genotypes $\left(F_{(2,12)}=15.09, p=0.0005\right)$, with significantly higher perforated synapse density in Shank3 heterozygous mice as compared to wildtype and Shank3 homozygous mice $(p<0.05$; Figs. $2 \mathrm{~b}$ and 3$)$. This increase did not persist into adulthood, as 3-month-old mice did not have significant differences across genotypes in perforated synapse density $\left(F_{(2,12)}=3.047, \quad p=0.085\right.$; Fig. 2b). A two-way ANOVA revealed a significant interaction between age and genotype in perforated synapse density $\left(F_{(2,24)}=10.569, p=0.001\right)$. To follow up on this interaction, we carried out a one-way ANOVA controlling for age, with genotype as a factor. As expected, there was a significant difference in perforated synapse density between

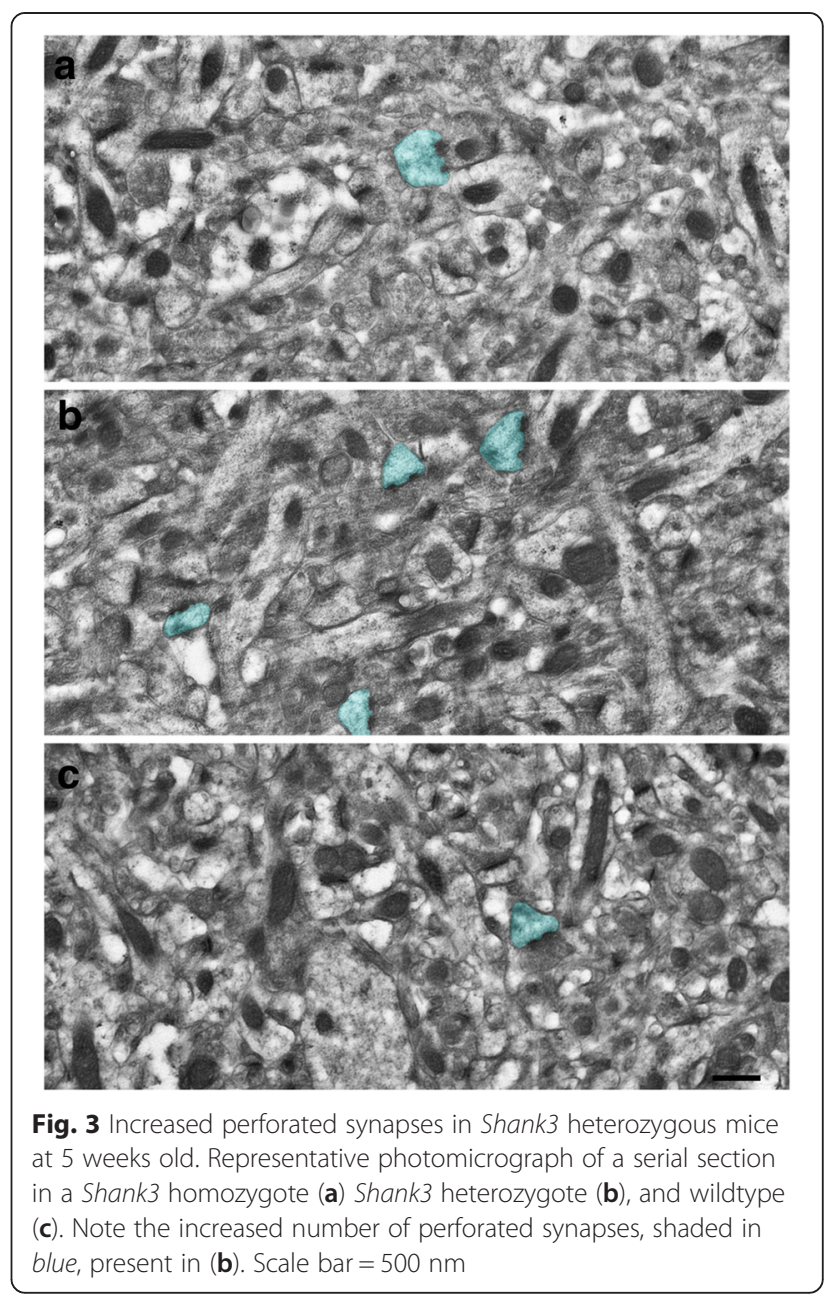

genotypes $\left(\mathrm{F}_{(2,479)}=17.85, p<0.001\right)$. A Tukey post hoc test revealed that Shank3 heterozygotes had significantly greater perforated synapse density than wildtype $(p<0.001)$ and Shank3 homozygotes $(p<0.001)$, though the difference was not significant between wildtype and Shank3 homozygotes $(p=0.848)$.

We then analyzed 5-week-old and 3-month-old mice for changes in spine head size, length of the PSD, and area of the PSD. There was no difference in average spine head size in the 5 -week-old mice $\left(F_{(2,12)}=0.551\right.$, $p=0.59$; Fig. 4a) or 3-month-old mice $\left(F_{(2,12)}=0.899\right.$, $p=0.433$, Fig. $4 \mathrm{a})$ nor was there an interaction effect of age and genotype on spine head size $\left(F_{(2,24)}=1.243\right.$, $p=0.306)$. There was no significant difference between genotypes in the PSD length in 5-week-old mice $\left(F_{(2,12)}=0.976, p=0.405\right.$; Fig. 4b), 3-month-old mice $\left(F_{(2,12)}=3.477, p=0.064\right.$, Fig. $\left.4 \mathrm{~b}\right)$, or across development $\left(F_{(2,24)}=2.308, p=0.121\right)$. PSD area was also the same across genotypes in 5-week-old mice $\left(F_{(2,12)}=\right.$ $0.714, p=0.509$, Fig. 4c), 3-month-old mice $\left(F_{(2,12)}=\right.$ 


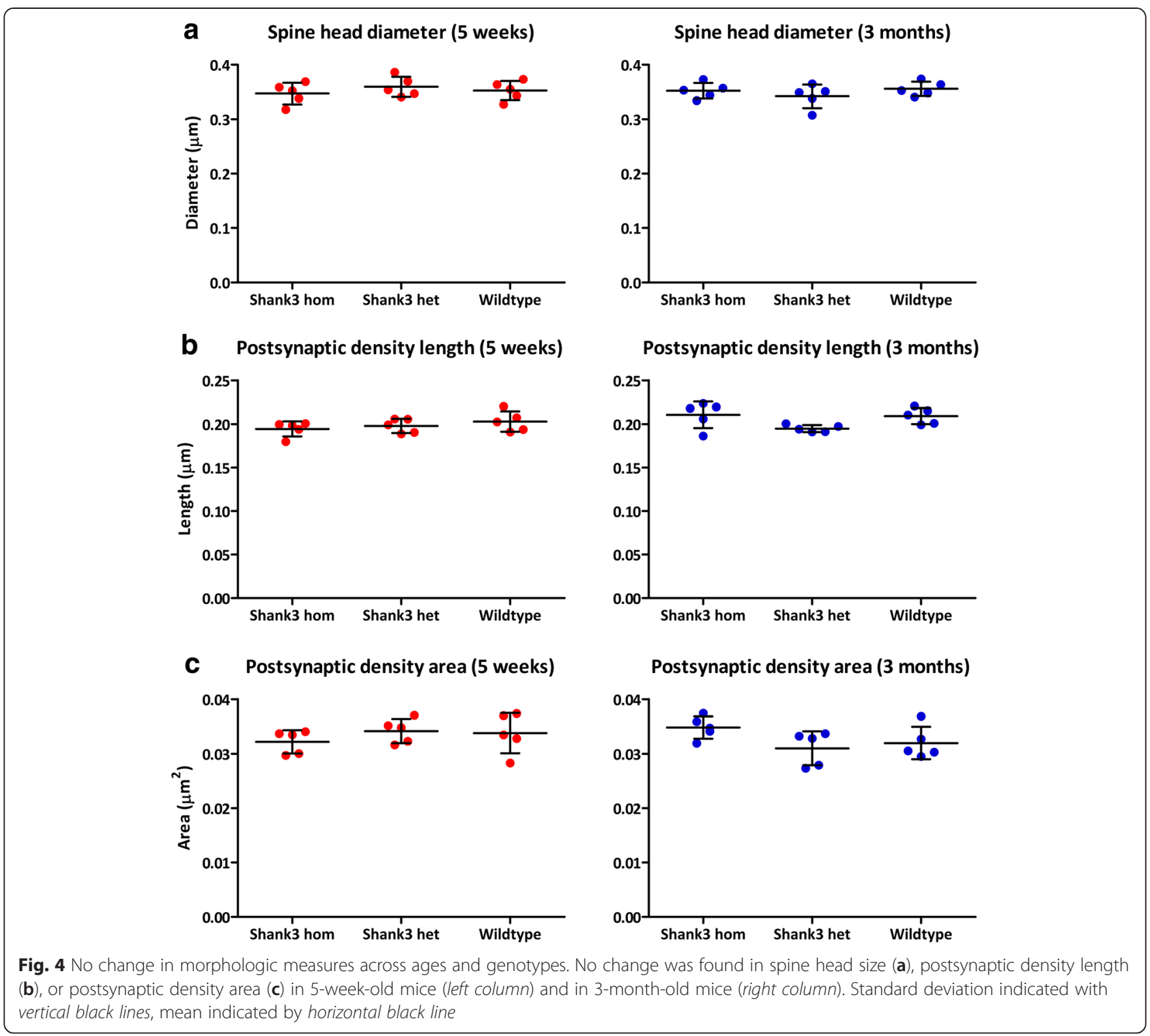

2.067, $p=0.115$, Fig. 4c), and across both developmental stages $\left(F_{(2,24)}=3.021, p=0.068\right)$.

\section{Discussion}

The Shank family of postsynaptic scaffolding proteins consists of three members (Shank1, Shank2, and Shank3; $[21,22])$. Shank1 and Shank3 mRNA transcripts are strongly expressed in the pyramidal and molecular layers of the hippocampus, indicating dendritic localization, whereas Shank2 mRNA transcripts are restricted to cell bodies [29, 42]. Shank2 protein localizes at the PSD early (prior to PSD-95 and NR1; [30]) and is thought to act as an initial "organizer" of the PSD; Shank3 is recruited next, interacting with Homer1b to create a complex on which postsynaptic proteins, such as GKAP, can bind [43]; lastly,
Shank1 enters after the PSD-95/GKAP complex is in place to stabilize synapses and may have a role in activityinduced regulation of spine head size [22, 44, 45].

With the loss of a major synaptic scaffolding protein, we expected to find significant morphologic changes in the Shank3-deficient mice. However, Shank3 heterozygous and homozygous mice exhibited no difference in spine head size, PSD length, and PSD area when compared to wildtype mice. This result suggests that the absence of Shank3 may be compensated for or may lead to deficits that are only observed early in development. Two obvious candidates for this compensation are Shank1 and Shank2. Shank2 is more similar to Shank3 in its recruitment to the synapse and its protein structure, making it a more likely candidate for compensation 
[20]. In fact, Shank3 was thought to compensate for Shank2 in Shank2-deficient mice, while Shank2 was thought to compensate for Shank3 in another form of Shank3 variant homozygous mice, as indicated by the upregulation of Shank3 at the synapse in Shank2 homozygous mice and vice versa [46].

In Shank3 heterozygotes, there is still one functional copy of Shank3, and therefore, a proportional amount of Shank3 protein is present at the synapse [27]. A reduced amount of Shank3 could affect multiple associated proteins $[20,22,43,44,47]$ and may result in changes in protein composition at the synapse, which may explain functional impairment in Shank3 heterozygous and homozygous mice [27, 28, 48]. While the Shank family does have highly conserved proteinprotein interaction domains, they are not redundant; each Shank protein can have specific mechanisms and proteins it targets [20]. Thus, while replacing one Shank protein with another might prevent the synapse from disassembling, it does not guarantee appropriate functioning. This is well illustrated through the mild behavioral abnormalities in these mice, consistently showing impairments in juvenile reciprocal interactions, novel object recognition, and rotarod performance [27, 28]. The mice also showed some evidence for excess self-grooming, reduced ultrasonic vocalizations, and impaired reversal of water maze learning.

The fact that synapse density was not changed despite the marked LTP deficit may reflect that a portion of the synapses in Shank3 variant mice may be "silent synapses" that have NMDA but not AMPA receptors, rendering the synapse non-functional [49]. Silent synapses are present in wildtype mice as well, forming during LTP induction and often undergoing remodeling to become functional during LTP maintenance $[50,51]$. It is possible that to compensate for the increase in silent synapses in Shank3-deficient mice at baseline, some silent synapses undergo remodeling to form perforated synapses, which are thought to have a higher efficacy of synaptic transmission $[52,53]$. The presence of increased silent synapses is corroborated by reduced basal synaptic transmission in both Shank3 heterozygous and homozygous mice $[27,28]$ and reflects a reduction in AMPA receptors, as they are constitutively active even during basal conditions [54]. In fact, a decrease in GluA1-immunoreactive puncta in CA1 was previously reported in Shank3 heterozygous mice, indicating a decrease in AMPA receptors [27]. This is substantiated by

a Wildtype mice

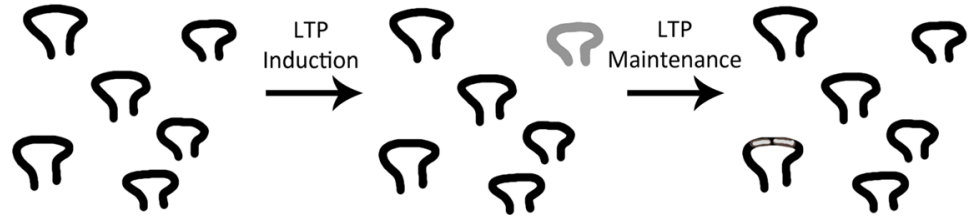

b Shank3 heterozygous mice

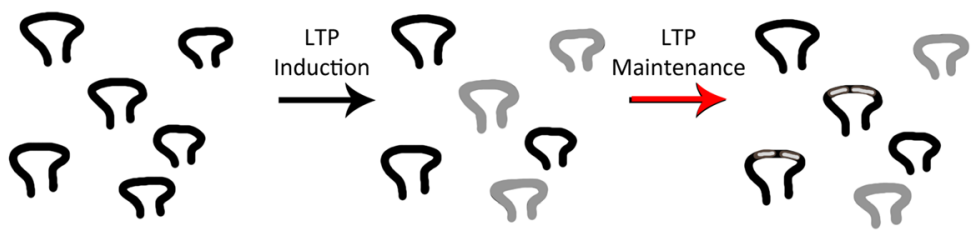

C Shank3 homozygous mice

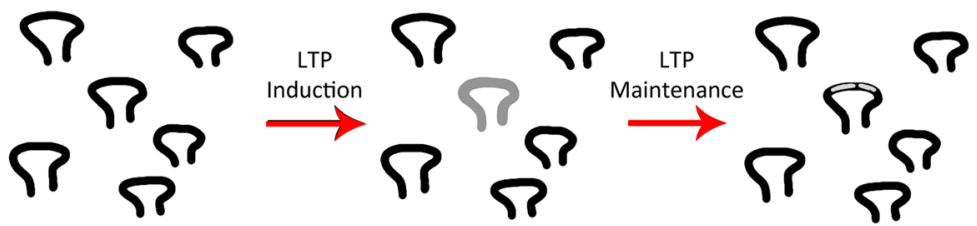

Fig. 5 Schematic of suggested mechanism of increased perforated synapse density. a Wildtype mice have silent synapses which are remodeled into non-perforated and perforated synapses. $\mathbf{b}$ Shank3 heterozygous mice have an increase in perforated synapses, which may not be remodeled into non-perforated synapses due to impaired LTP maintenance. c Shank3 homozygous mice have impairments in LTP induction and maintenance, which may be why the increase in perforated synapses, which is thought to be compensatory, does not occur. Black synapses indicate non-perforated synapses; gray synapses indicate silent synapses; black synapses with perforations indicate perforated synapses. Red arrows indicate mechanisms that are impaired 
the significant impairment in the maintenance phase of LTP, which is AMPA receptor-dependent [27].

The results of this study indicate that 5-week-old Shank3 heterozygous mice have a significant increase in perforated synapses. While the overall sample is sizeable for an electron microscopy study, we do realize that an $n$ of 5 for each group is small; as such, the caveat that the results may be due to a type I error does arise. In order to resolve this issue, further research with a larger population of mice will be necessary. Nevertheless, the above results suggest the occurrence of a significant increase in perforated spines accompanied by impaired LTP maintenance [27] and of an increase in perforated synapses, which may be providing some, yet insufficient, compensation for an increased amount of silent, nonfunctional synapses. The remodeling of perforated synapses back into non-perforated synapses occurs during LTP maintenance [50]; however, as LTP maintenance is impaired, this remodeling may not occur, possibly underlying the consistent increase in the amount of perforated synapses. The relative decrease in perforated synapse density to "normal" levels in Shank3 heterozygous mice at 3 months may be a reflection of a normalization of functional activity with age, as silent synapses can be transiently silent, thereby reducing the need for perforated synapses. Notably, the Shank3 homozygous mice showed no difference in perforated synapses at 5 weeks (Fig. 2b), despite the substantial impairment in LTP. This may occur because perforated synapses are formed during LTP induction [55], which is significantly impaired in Shank3 homozygous mice; this impairment may hinder the formation of perforated synapses (see Fig. 5).

While there are no directly correlated studies on synaptic morphology measures in individuals with autism or PMS in the hippocampus, there are several studies that imply alterations at the synaptic level. Neuropathology studies have revealed abnormalities in neuronal numbers [1-6], and imaging studies have revealed a variable degree of altered connectivity localized to specific areas (e.g., [56, 57]). Additionally, work at the protein level has shown abnormalities in receptors in the hippocampus, which may reflect changes at the synapse as well $[58,59]$. In accordance with these studies, it will be crucial to use electron microscopy to assess whether there are changes in the synapse at the protein level. Future studies will also expand the age range in these mice, particularly at a younger age as autism is a neurodevelopmental disorder; additionally, expanding the number of mice per group will allow for stronger conclusions regarding the synaptic alterations in these mice.

\section{Conclusions}

This study examined whether synaptic pathology was present in Shank3 heterozygous and Shank3 homozygous mice at 5 weeks and 3 months of age. Shank3 heterozygous mice (5-weeks-old) had a statistically significantly higher density of perforated synapses and no change in other measured parameters (synapse density, PSD length, PSD area, and spine head size); 3-monthold mice had no changes across groups for any measured parameter. It is remarkable that there are so few detectable behavioral and neuropathologic changes in these Shank3 variant mice despite the loss of this dominant scaffolding protein. These results highlight the importance of seeking even more subtle alterations, in the form of changes in specific protein levels, at the synapses of these mice. Understanding the subtle effects of this single-locus cause of autism will provide a framework for similar explorations in other genetic causes associated with the disorder, which will allow us to determine whether alterations in these disparate genes lead to similar effects at the most basic functional level, namely, the synapse.

\section{Abbreviations \\ AMPA: a-amino-3-hydroxy-5-methyl-4-isoxazole propionic acid; ANOVA: analysis of variance; GluA1: glutamate receptor subunit 1; LTP: long- term potentiation; NMDA: N-methyl-D-aspartic acid; PB: phosphate buffer; PBS: phosphate buffer with saline; PMS: Phelan-McDermid syndrome; PSD: postsynaptic density; SHANK3: SH3 and multiple ankyrin repeat domains 3.}

\section{Competing interests}

The authors declare that they have no competing interests.

\section{Authors' contributions}

NU contributed to study design; imaged, analyzed, and interpreted data; and wrote the manuscript. RP and FY processed tissue. WGMJ contributed to study design and processed tissue. OB-G contributed to study design and data interpretation. HH-N contributed to study design and data interpretation. DLD perfused mice, processed tissue, and contributed to study design. JDB contributed to study concept, study design and coordination, interpreted data, and critically revised the manuscript. PRH contributed to study concept, study design and coordination, interpreted data, and critically revised the manuscript. All authors have read and approved the final manuscript.

\section{Acknowledgements}

The authors greatly appreciate the expertise and guidance of Dr. Yuko Hara in electron microscopy techniques and data interpretation. They would also like to thank Dr. Lilijana Minwalla for expert technical assistance and Dr. James Schmeidler for advice on statistical analyses.

\section{Author details}

${ }^{1}$ Fishberg Department of Neuroscience, Icahn School of Medicine at Mount Sinai, One Gustave L Levy Place, Box 1639, New York, NY 10029, USA. ${ }^{2}$ Friedman Brain Institute, Icahn School of Medicine at Mount Sinai, New York, NY, USA. ${ }^{3}$ Seaver Autism Center for Research and Treatment, Icahn School of Medicine at Mount Sinai, New York, NY, USA. ${ }^{4}$ Graduate School of Biomedical Sciences, Icahn School of Medicine at Mount Sinai, New York, NY, USA. ${ }^{5}$ Department of Psychiatry, Icahn School of Medicine at Mount Sinai, New York, NY, USA. ${ }^{6}$ The Sheryl and Daniel R. Tishman Cognitive Neurophysiology Laboratory, Department of Pediatrics, Albert Einstein College of Medicine, 1225 Morris Park Avenue, Bronx, NY 10461, USA. 
Received: 7 January 2015 Accepted: 22 June 2015

Published online: 30 June 2015

\section{References}

1. Casanova MF, van Kooten IA, Switala $A E$, van Engeland $H$, Heinsen $H$, Steinbusch HW, et al. Minicolumnar abnormalities in autism. Acta Neuropathol. 2006:112:287-303.

2. Jacot-Descombes S, Uppal N, Wicinski B, Santos M, Schmeidler J, Giannakopoulos $P$, et al. Decreased pyramidal neuron size in Brodmann areas 44 and 45 in patients with autism. Acta Neuropathol. 2012;124:67-79.

3. Raymond GV, Bauman ML, Kemper TL. Hippocampus in autism: a Golgi analysis. Acta Neuropathol. 1996;91:117-9.

4. Uppal N, Wicinski B, Buxbaum JD, Heinsen H, Schmitz C, Hof PR. Neuropathology of the anterior midcingulate cortex in young children with autism. J Neuropathol Exp Neurol. 2014;73:891-902.

5. van Kooten IA, Palmen SJ, von Cappeln P, Steinbusch HW, Korr H, Heinsen $\mathrm{H}$, et al. Neurons in the fusiform gyrus are fewer and smaller in autism. Brain. 2008;131:987-99

6. Wegiel J, Flory M, Kuchna I, Nowicki K, Ma SY, Imaki H, et al. Neuronal nucleus and cytoplasm volume deficit in children with autism and volume increase in adolescents and adults. Acta Neuropathol Commun. 2015;3:2.

7. Phelan MC, Rogers RC, Saul RA, Stapleton GA, Sweet K, McDermid H, et al. $22 q 13$ deletion syndrome. Am J Med Genet.

2001;101:91-9.

8. Cusmano-Ozog K, Manning MA, Hoyme HE. 22q13.3 deletion syndrome: a recognizable malformation syndrome associated with marked speech and language delay. Am J Med Genet C: Semin Med Genet. 2007;145C:393-8.

9. Dhar SU, del Gaudio D, German JR, Peters SU, Ou Z, Bader PI, et al. 22q13.3 deletion syndrome: clinical and molecular analysis using array $\mathrm{CGH}$. Am J Med Genet A. 2010;152A:573-81.

10. Phelan MC. Deletion 22q13.3 syndrome. Orphanet J Rare Dis. 2008;3:14.

11. Soorya L, Kolevzon A, Zweifach J, Lim T, Dobry Y, Schwartz L, et al. Prospective investigation of autism and genotype-phenotype correlations in 22 q13 deletion syndrome and SHANK3 deficiency. Mol Autism. 2013:4:18.

12. Anderlid BM, Schoumans J, Anneren G, Tapia-Paez I, Dumanski J, Blennow E, et al. FISH-mapping of a 100-kb terminal 22q13 deletion. Hum Genet. 2002;110:439-43.

13. Bonaglia MC, Giorda R, Beri S, De Agostini C, Novara F, Fichera M, et al. Molecular mechanisms generating and stabilizing terminal 22q13 deletions in 44 subjects with Phelan/McDermid syndrome. PLoS Genet. 2011;7:e1002173.

14. Bonaglia MC, Giorda R, Borgatti R, Felisari G, Gagliardi C, Selicorni A, et al Disruption of the ProSAP2 gene in a $t(12 ; 22)(q 24.1 ; q 13.3)$ is associated with the 22q13.3 deletion syndrome. Am J Hum Genet. 2001;69:261-8.

15. Bonaglia MC, Giorda R, Mani E, Aceti G, Anderlid BM, Baroncini A, et al. Identification of a recurrent breakpoint within the SHANK3 gene in the 22q13.3 deletion syndrome. J Med Genet. 2006;43:822-8.

16. Durand CM, Betancur C, Boeckers TM, Bockmann J, Chaste P, Fauchereau F, et al. Mutations in the gene encoding the synaptic scaffolding protein SHANK3 are associated with autism spectrum disorders. Nat Genet. 2007;39:25-7.

17. Marshall CR, Noor A, Vincent JB, Lionel AC, Feuk L, Skaug J, et al. Structural variation of chromosomes in autism spectrum disorder. Am J Hum Genet. 2008;82:477-88.

18. Moessner R, Marshall CR, Sutcliffe JS, Skaug J, Pinto D, Vincent J, et al. Contribution of SHANK3 mutations to autism spectrum disorder. Am J Hum Genet. 2007:81:1289-97.

19. Kreienkamp HJ. Scaffolding proteins at the postsynaptic density: Shank as the architectural framework. Handb Exp Pharmacol. 2008;186:365-80.

20. Sheng M, Kim E. The Shank family of scaffold proteins. J Cell Sci. 2000;113:1851-6.

21. Boeckers TM, Winter C, Smalla KH, Kreutz MR, Bockmann J, Seidenbecher C, et al. Proline-rich synapse-associated proteins ProSAP1 and ProSAP2 interact with synaptic proteins of the SAPAP/GKAP family. Biochem Biophys Res Commun. 1999;264:247-52.

22. Naisbitt S, Kim E, Tu JC, Xiao B, Sala C, Valtschanoff J, et al. Shank, a novel family of postsynaptic density proteins that binds to the NMDA receptor/ PSD-95/GKAP complex and cortactin. Neuron. 1999;23:569-82.
23. Tu JC, Xiao B, Naisbitt S, Yuan JP, Petralia RS, Brakeman P, et al. Coupling of mGluR/Homer and PSD-95 complexes by the Shank family of postsynaptic density proteins. Neuron. 1999;23:583-92.

24. Uchino S, Wada H, Honda S, Nakamura Y, Ondo Y, Uchiyama T, et al. Direct interaction of post-synaptic density-95/Dlg/ZO-1 domain-containing synaptic molecule Shank3 with GluR1 alpha-amino-3-hydroxy-5-methyl-4-isoxazole propionic acid receptor. J Neurochem. 2006;97:1203-14.

25. Yao I, Hata Y, Hirao K, Deguchi M, Ide N, Takeuchi M, et al. Synamon, a novel neuronal protein interacting with synapse-associated protein 90/ postsynaptic density-95-associated protein. J Biol Chem. 1999;274:27463-6.

26. Sugiyama Y, Kawabata I, Sobue K, Okabe S. Determination of absolute protein numbers in single synapses by a GFP-based calibration technique. Nat Methods. 2005;2:677-84.

27. Bozdagi O, Sakurai T, Papapetrou D, Wang X, Dickstein DL, Takahashi N, et al, Haploinsufficiency of the autism-associated Shank3 gene leads to deficits in synaptic function, social interaction, and social communication. Mol Autism. 2010;1:15.

28. Yang M, Bozdagi O, Scattoni ML, Wohr M, Roullet Fl, Katz AM, et al. Reduced excitatory neurotransmission and mild autism-relevant phenotypes in adolescent Shank3 null mutant mice. J Neurosci. 2012:32:6525-41.

29. Böckers TM, Segger-Junius M, Iglauer P, Bockmann J, Gundelfinger ED, Kreutz $M R$, et al. Differential expression and dendritic transcript localization of Shank family members: identification of a dendritic targeting element in the $3^{\prime}$ untranslated region of Shank1 mRNA. Mol Cell Neurosci. 2004;26:182-90.

30. Boeckers TM, Kreutz MR, Winter C, Zuschratter W, Smalla KH, Sanmarti-Vila L, et al. Proline-rich synapse-associated protein-1/cortactin binding protein 1 (ProSAP1/CortBP1) is a PDZ-domain protein highly enriched in the postsynaptic density. J Neurosci. 1999;19:6506-18.

31. Geinisman $Y$, de Toledo-Morrell L, Morrell F. Aged rats need a preserved complement of perforated axospinous synapses per hippocampal neuron to maintain good spatial memory. Brain Res. 1986;398:266-75.

32. Geinisman Y, de Toledo-Morrell L, Morrell F. Loss of perforated synapses in the dentate gyrus: morphological substrate of memory deficit in aged rats. Proc Natl Acad Sci U S A. 1986;83:3027-31.

33. Jones DG, Harris RJ. An analysis of contemporary morphological concepts of synaptic remodeling in the CNS: perforated synapses revisited. Rev Neurosci. 1995;6:177-219.

34. Geinisman Y, Disterhoft JF, Gundersen HJ, McEchron M, Persina IS, Power $J M$, et al. Remodeling of hippocampal synapses after hippocampusdependent associative learning. J Comp Neurol. 2000;417:49-59.

35. Nicholson DA, Yoshida R, Berry RW, Gallagher M, Geinisman Y. Reduction in size of perforated postsynaptic densities in hippocampal axospinous synapses and age-related spatial learning impairments. J Neurosci. 2004;24:7648-53.

36. Ganeshina O, Berry RW, Petralia RS, Nicholson DA, Geinisman Y. Differences in the expression of AMPA and NMDA receptors between axospinous perforated and nonperforated synapses are related to the configuration and size of postsynaptic densities. J Comp Neurol. 2004:468:86-95.

37. Carlin RK, Siekevitz P. Plasticity in the central nervous system: do synapses divide? Proc Natl Acad Sci U S A. 1983;80:3517-21.

38. Jones DG. Synaptic plasticity and perforated synapses: their relevance for an understanding of abnormal synaptic organization. APMIS Suppl. 1993:40:25-34

39. Sorra K, Fiala JC, Harris K. Critical assessment of the involvement of perforations, spinules, and spine branching in hippocampal synapse formation. J Comp Neurol. 1998;398:225-40.

40. Bloss EB, Puri R, Yuk F, Punsoni M, Hara Y, Janssen WG, et al. Morphological and molecular changes in aging rat prelimbic prefrontal cortical synapses. Neurobiol Aging. 2013;34:200-10.

41. Adams MM, Shah RA, Janssen WG, Morrison JH. Different modes of hippocampal plasticity in response to estrogen in young and aged female rats. Proc Natl Acad Sci U S A. 2001;98:8071-6.

42. Lim S, Naisbitt S, Yoon J, Hwang Jl, Suh PG, Sheng M, Kim E. Characterization of the Shank family of synaptic proteins. Multiple genes, alternative splicing, and differential expression in brain and development. J Biol Chem. 1999;274:29510-8.

43. Hayashi MK, Tang C, Verpelli C, Narayanan R, Stearns MH, Xu RM, et al. The postsynaptic density proteins Homer and Shank form a polymeric network structure. Cell. 2009;137:159-71. 
44. Boeckers TM, Liedtke T, Spilker C, Dresbach T, Bockmann J, Kreutz MR, et al. C-terminal synaptic targeting elements for postsynaptic density proteins ProSAP1/Shank2 and ProSAP2/Shank3. J Neurochem. 2005;92:519-24.

45. Tao-Cheng JH, Dosemeci A, Gallant PE, Smith C, Reese T. Activity induced changes in the distribution of Shanks at hippocampal synapses. Neuroscience. 2010;168:11-7.

46. Schmeisser MJ, Ey E, Wegener S, Bockmann J, Stempel AV, Kuebler A, et al. Autistic-like behaviours and hyperactivity in mice lacking ProSAP1/Shank2. Nature. 2012;486:256-60.

47. Sala C, Piech V, Wilson NR, Passafaro M, Liu G, Sheng M. Regulation of dendritic spine morphology and synaptic function by Shank and Homer. Neuron. 2001:31:115-30.

48. Grabrucker AM. A role for synaptic zinc in ProSAP/Shank PSD scaffold malformation in autism spectrum disorders. Dev Neurobiol. 2013;74:136-46.

49. Isaac JT, Nicoll RA, Malenka RC. Evidence for silent synapses: implications for the expression of LTP. Neuron. 1995;15:427-34

50. Geinisman Y. Structural synaptic modifications associated with hippocampal LTP and behavioral learning. Cereb Cortex. 2000;10:952-62.

51. Liao D, Hessler NA, Malinow R. Activation of postsynaptically silent synapses during pairing-induced LTP in CA1 region of hippocampal slice. Nature. 1995;375:400-4.

52. Harris KM, Jensen FE, Tsao B. Three-dimensional structure of dendritic spines and synapses in rat hippocampus (CA1) at postnatal day 15 and adult ages: implications for the maturation of synaptic physiology and long-term potentiation. J Neurosci. 1992;12:2685-705.

53. Peters A, Kaiserman-Abramof IR. The small pyramidal neuron of the rat cerebral cortex: the synapses upon dendritic spines. Z Zellforsch Mikrosk Anat. 1969;100:487-506.

54. Shepherd JD, Huganir RL. The cell biology of synaptic plasticity: AMPA receptor trafficking. Annu Rev Cell Dev Biol. 2007;23:613-43.

55. Geinisman Y, de Toledo-Morrell L, Morrell F. Induction of long-term potentiation is associated with an increase in the number of axospinous synapses with segmented postsynaptic densities. Brain Res. 1991;566:77-88.

56. Schultz RT. Developmental deficits in social perception in autism: the role of the amygdala and fusiform face area. Int J Devl Neuroscience. 2005;23:125-41.

57. Schumann CM, Hamstra J, Goodlin-Jones BL, Lotspeich $\amalg$, Kwon H, Buonocore $\mathrm{MH}$, et al. The amygdala is enlarged in children but not adults with autism; the hippocampus is enlarged at all ages. J Neurosci. 2004;24:6392-401.

58. Blatt GJ, Fitzgerald CM, Guptill JT, Booker AB, Kemper TL, Bauman ML. Density and distribution of hippocampal neurotransmitter receptors in autism: an autoradiographic study. J Autism Dev Disord. 2001;31:537-43.

59. Guptill JT, Booker AB, Gibbs TT, Kemper TL, Bauman ML, Blatt GJ. [3H]flunitrazepam-labeled benzodiazepine binding sites in the hippocampal formation in autism: a multiple concentration autoradiographic study. J Autism Dev Disord. 2007;37:911-20.

\section{Submit your next manuscript to BioMed Central and take full advantage of:}

- Convenient online submission

- Thorough peer review

- No space constraints or color figure charges

- Immediate publication on acceptance

- Inclusion in PubMed, CAS, Scopus and Google Scholar

- Research which is freely available for redistribution 